\title{
ВПЛИВ ГАРМОНІЗАЦІЇ ОСВІТНІХ СТАНДАРТІВ НА РОЗВИТОК ЦІННІСНИХ ОРІЕНТИРІВ ОСОБИСТОСТІ
}

\author{
THE IMPACT OF HARMONIZATION \\ OF EDUCATIONAL STANDARDS \\ ON THE DEVELOPMENT OF PERSONAL VALUES
}

\author{
Шульгіна Людмила Михайлівна \\ доктор економічних наук, професор, \\ Національний технічний університет \\ «Київський політехнічний інститут імені Ігоря Сікорського» \\ ORCID: https://orcid.org/0000-0001-9554-6185 \\ Жалдак Ганна Петрівна \\ кандидат економічних наук, \\ Національний технічний університет \\ «Київський політехнічний інститут імені Ігоря Сікорського» \\ ORCID: https://orcid.org/0000-0003-3421-3648
}

Shulgina Liudmyla, Zhaldak Hanna
National Technical University of Ukraine
"Igor Sikorsky Kyiv Polytechnic Institute"

У статті вказано на необхідність і актуальність зменшення розриву між темпами технологічного та гуманітарного розвитку суспільства з метою запобігання ризикам, спричиненим недостанім рівнем підготовленості користувачів сучасних технологій. Обгрунтовано доцільність посилення гуманітарної складової у виховному процесі. На основі методу кабінетного контент-аналізу проілюстровано деякі структурні та змістовні відмінності між нормативними документами, показано позитивний влив гармонізації законодавства у галузі освіти, а також розроблення освітніх стандартів на формулювання у цих документах ціннісних орієнтирів особистості. Проведено оцінювання групи морально-етичних характеристик студентів і викладачів України та Польщі. Встановлено порівняно низький рівень присутності характеристик, що складають ціннісні орієнтири представників обстежуваних груп. Отримані у ході спостереження дані, викладені у цій статті, були підтверджені даними, зібраними методом глибинного інтерв'ювання учасників освітнього процесу.

Ключові слова: ціннісні орієнтири особистості, морально-етичні характеристики, стандарти освіти, гармонізація стандартів.

В статье указано на необходимость и актуальность уменьшение разрыва между темпами технологического и гуманитарного развития общества с целью предотвращения рисков, вызываемых недостаним уровнем подготовленности пользователей современных технологий. Обоснована целесообразность усиления гуманитарной составляющей в воспитательном процессе. На основе метода кабинетного контент-анализа проиллюстрировано некоторые структурные и содержательные различия между нормативными документами, показано положительное влияние гармонизации законодательства в области образования, а также разработка образовательных стандартов на формулировки в этих документах ценностных ориентиров личности. Проведена оценка группы морально-этических характеристик студентов и преподавателей Украины и Польши. Установлено сравнительно низкий уровень присутствия характеристик, составляющих ценностные ориентиры представителей обследуемых групп. Полученные в ходе наблюдения данные, изложенные в этой статье, были подтверждены данными, собранными методом глубинного интервьюирования участников образовательного процесса.

Ключевые слова: ценностные ориентиры личности, морально-этические характеристики, стандарты образования, гармонизация стандартов.

The article points to the need and urgency of changing the difference in the pace of technological and humanitarian development of society in order to spare the risks caused by the lack of preparedness of users of modern 
technology. The expediency of strengthening the humanitarian component in the educational process is substantiated. Based on the method of office content analysis, some structures and variable differences between normative documents are illustrated, the positive level of harmonization of legislation in the field of education is shown, as well as the development of educational standards in the formulation of these documents. The groups of moral and ethical characteristics of students and teachers of Ukraine and Poland were evaluated. A relatively low level of presence of characteristics that make up the values of the representatives of the surveyed groups. The positive and negative dynamics of various indicators have been removed. A comparative evaluation of the studied characteristics between the representatives of Ukraine and Poland was performed. An explanation of the identified differences is given. The results of the observation indicate the absence of the presence in the complex of characteristics of the modern personality of those important value orientations that testified to the readiness of people who make up society, reporting possible risks of new technologies and ensuring their safe use at all levels. It is determined that society under the influence of educators and their students gradually improves All indicators that characterize the level of development of various aspects of public life, namely: the state of the economy, political and legal system, ecology, medicine, duration and quality of life, crime, aggression. during the observation, the data presented in this article were confirmed by the data collected by the method of in-depth interviews of participants in the educational process. The results of the observation presented in this article testify to the insufficient presence in the complex of characteristics of the modern personality of those important value orientations that would indicate the readiness of people who make up society to realize the possible risks of new technologies and ensure their safe use at all levels.

Keywords: personality guidelines, moral and ethical characteristics, educational standards, harmonization of standards.

Постановка проблеми. Прискорений розвиток різного роду технологій, спричинений головним чином динамікою змін в інфрормаційних технологіях, впливає як на усі ссрери життєдіяльності людини (незалежно від роду діяльності), так і на усі рівні організації людського життя у соціумі від індивідів та їх груп у межах однієї локації аж до глобального масштабу. Максимально узагальнивши наслідки технологічного розвитку, зведемо їх до двох позицій, що на наш погляд $є$ найбільш очевидними: 1) зростання темпу життя людей і 2) збільшення масштабів їх діяльності. Кожна з названих двох ознак сучасності, безумовно, відкриває неймовірно привабливі горизонти фрінансового успіху для адекватно підготовленої особистості чи груп таких особистостей, об'єднаних у підприємства, організації, альянси і ін.

Однак, автори пропонованої статті при цьому вважають за необхідне акцентувати увагу на виразі «адекватно підготовлена особистість», наше тлумачення цього виразу ми детально розглянемо нижче. Маємо на увазі, що в протилежному випадку, тобто якщо особистість $€$ непідготовленою або рівень ії підготовленості до виконання певних фрункцій викликає сумніви, одночасно з набутими технологічними можливостями у сучасному прискореному і глобалізованому світі зростають також і ризики. 3розуміло, що чим вища посада, яку обіймає така особистість, і чим більший масштаб її впливу, тим вищий рівень настання ризикових (негативних) наслідків її діяльності.

Аналіз досліджень і постановка завдання. У нас немає підстав стверджувати, що саме усвідомлення імовірності виникнення ризиків від діяльності впливових, активних і непідготовлених користувачів сучасних технологій стало першопричиною розроблення стандартів освіти в усіх країнах. Аналіз джерел та законодавства вказує на переважання соціально-економічних і політико-правових драйверів започаткування стандарто-фрормуючої діяльності [1-5]. Проте зростаюча невідповідність між очікуваними і отримуваними результатами соціально-економічного розвитку в усіх країнах в умовах поглиблення глобальних проблем у світі [5-10], а також значна кількість невдалих рішень щодо розв'язання згаданих проблем [10] спонукає нас до постановки цілого ряду запитань. Ключове 3 них вбачається таким: яким чином передбачити і зафріксувати у стандартах освіти запобіжники розриву між темпами технологічного та гуманітарного розвитку суспільства.

Інакше кажучи, ми переконані в актуальності, a, отже, і необхідності більш глибокого дослідження такого припущення: ціннісні орієнтири у діючих освітніх стандартах виписані недостатньо чітко (або взагалі не прописані), внаслідок чого увага до формування спеціальних компетенцій учнів/студентів для виконання ними фрункцій як спеціалістів у певній галузі $€$ незрівнянно більшою, ніж увага до їх розвитку як високоморальних і фрізично розвинених особистостей, здатних до творчої праці і фрормування майбутнього більш ефективного суспільства. Один із наслідків цієї диспропорції, який є предметом дослідження, ми сорормулювали так: темпи розвитку технологій у сучасному суспільстві значно випереджають розвиток такої особистості, яку можна 
було б характеризувати як високо-гуманну та соціально-відповідальну. Розуміючи, що піднята проблема $€$ надзвичайно складною, багатоаспектною і неоднозначною, ми зосередили нашу увагу виключно на вивченні можливості визначити і в перспективі удосконалювати інструменти її вирішення, у т.ч. через стандарти освіти.

Аналіз досліджень та публікацій. Теоретичним підґрунтям і методологічною базою нашого дослідження $€$ фрундаментальні положення нормативно-правових документів (стандартів), напрацювання вітчизняних та іноземних вчених, що стосуються ціннісних орієнтирів особистості в контексті гармонізації освітніх стандартів України зі стандартами ЄС.

Для досягнення поставленої мети застосували методи: логічного узагальнення, аналізу та синтезу, використовували кабінетний і контент-аналіз, також було проведено включене та невключене польове спостереження, у якому одиницями обстеження виступали учасники освітнього процесу: 436 студентів, 257 викладачів та представників адміністрації українських і польських університетів.

Метою статті $€$ визначення впливу гармонізації освітніх стандартів України та ЄС на розвиток ціннісних орієнтирів особистості шляхом представлення результатів компаративного аналізу змісту освітніх законів і стандартів України та ЄС (на прикладі Польщі), а також даних дослідження ціннісних орієнтирів особистості на прикладі студентів і викладачів України та Польщі.

Виклад основного матеріалу дослідження. У літературі існують різні підходи до визначення та характеристики ціннісних орієнтирів особистості. Ми базувалися на підході, викладеному у концепції «Нової української школи», відповідно до якого, ціннісні орієнтири (ЦО) учня мають такі складові: морально-етична (гідність, рівність, справедливість, толерантність та культурне різноманіття, турбота, чесність, довіра); соціальноправова (верховенство права, нетерпимість до корупції та фраворитизму, патріотизм, екологічно-етична цінність, соціальна відповідальність) та особистісно зорієнтована (самореалізація, лідерство, свобода). Відображення змісту ЦО, задекларованих у згаданій Концепції, знаходимо у законах про освіту та вищу освіту, а також освітніх стандартах.

Таким чином, на підставі контент-аналізу узгодженості ЦО особистості у положеннях освітніх стандартів України та Польщі попередній висновок можна сорормулювати так: незважаючи на деякі структурні невідповідності та відсутність в українських документах уваги до виховання патріотизму, толерантності, поваги до прав (включаючи права меншин), необхідності мислити саме критично (а не лише абстрактно), знання не менше ніж двох іноземних мов (а не однієі) та ще деяких інших акцентів, що на наш погляд $є$ необхідними, аналізовані документи змістовно дуже близькі, принаймні на рівні декларацій.

Цілком очікуваним результатом аналізу змісту документів (освітніх стандартів, положень, кодексів тощо), аналогічних до згаданих вище і розроблених у різних університетах України та Польщі, було встановлення того фракту, що усі вони декларують високі моральні принципи та норми поведінки учасників освітнього процесу. Це й не дивно 3 огляду на фрормулювання цілей освіти у відповідних законах / освітніх стандартах і розвиток та деталізацію цих цілей у похідних документах. Тому метою наступних етапів нашого дослідження було встановити щільність зв'язків між: 1) декларацією ЦО у зазначених документах та 2) їх втіленням учасниками освітнього процесу у реальному житті.

У дослідженнях виходили 3 такого ланцюжка припущень, що характеризують ідеальний (тобто не досягнутий, а бажаний) морально-етичний стан університетського середовища:

- по-перше, гуманітарні цілі освіти (у т.ч. і вищої) існують тривалий період часу, адже подібні формулювання мали також і попередники сучасних документів (наприклад, Закон УРСР «Про освіту» та ін.), тобто ці цілі перевірені часом, з чого випливає, що ЦО викладачів упродовж цього тривалого часу до сьогодні вже мають перерости у тверді переконання та моделі поведінки, які б свідчили про їх високі морально-етичні і інші життєві принципи;

- по-друге, реалізація цих принципів у відповідних моделях поведінки є підставою для сприйняття викладачів та адміністрації університетів іншими реорерентними групами суспільства (у т.ч. студентами) як справжньої еліти суспільства, яку ці групи прагнуть наслідувати, поступово удосконалюючи тим самим і все суспільство;

- по-третє, на шкалі еволюції суспільство під впливом освітян і їх учнів поступово покращує усі показники, що характеризують рівень розвитку різних аспектів суспільного життя, а саме: стан економіки, політико-правової системи, екології, медицини, тривалості та якості життя, рівня злочинності, агресії і т.д. 
Звичайно, наведений логічний ланцюжок ідеального втілення ЦО в життя можна було б продовжувати, деталізуючи на різних рівнях: особистості, родини, спільноти, нації і навіть людства. Однак, реальність переконує у недоцільності такого продовження, наводячи практично щодня приклади, які характеризують стан суспільства в цілому і університетських спільнот зокрема як далекий від ідеального. Свідчить про це також і фррагмент узагальнених результатів спостереження за поведінкою членів двох ресрерентних груп українських університетів (студентів і викладачів) упродовж тривалого часу (2002-2020рр.), що представлений на рис. 1.

Для фрормування профрілів ЦО учасників освітнього процесу (рис. 1) здійснили кілька узагальнень. По-перше, використали середнє арифметичне значення оцінок певних характеристик особистості, отриманих у ході спостереження за представниками однієї референтної групи або одного «гнізда», де «гніздо»- це групастудентів певної спеціальності. По-друге, усереднили ці оцінки між різними «стратами», де «страта» - це рік навчання, однак, виявлені відмінності не дали підстав вважати студентів різних років навчання представниками різних страт. По-третє, ту саму операцію здійснили послідовно на другому та третьому рівні «гнізд» - фракультетів та університетів. По-четверте, знайшли середнє у межах вказаних двох періодів дослідження. По-п'яте, на кожному етапі узгоджували між собою оцінки спостерігачів, а також брали до уваги оціночні судження інших учасників освітнього процесу.
Для викладачів описана вище послідовність узагальнень на першому етапі мала вигляд визначення оцінок всередині «гнізд», які фрормувалися на основі позиції викладача у колективі за двома критеріями: а) серед науковців - аспірант, кандидат наук, доктор наук; б) серед посадовців - асистент, старший викладач, доцент, профресор, завідувач кафедри, декан). На другому етапі усереднювали оцінки між «гніздами».

У ході аналізу отриманих даних встановлено кілька явищ, що на наш погляд варті посиленої уваги.

Перше: найбільші відмінності між оцінками в обох підгрупах виявлені у межах першого рівня гнізда, тобто - однієї студентської групи та однієї наукової та/чи посадової позиції викладачів. Це підтвердило відому тезу, про сорормованість особистості ще до вступу до університету, а звідси незначний вплив на студентів таких чинників як спеціалізація, рік навчання, фракультет та/чи університет, а також наукова чи посадова позиція - на викладачів. Інакше кажучи, найбільшу амплітуду значень мали оцінки, які підлягали найпершому усередненню, а всі решта були на рівні статистичної похибки. Крім того, оцінки в обох підгрупах були досить близькими, а це дозволило сорормулювати два припущення: 1) статус і вік мають, порівняно, незначний вплив на вже сорормовані цінності; 2) студенти $€$ дійсно віддзеркаленням невисокого рівня ЦО тих особистостей і суспільних груп, що впливали на них упродовж життя.

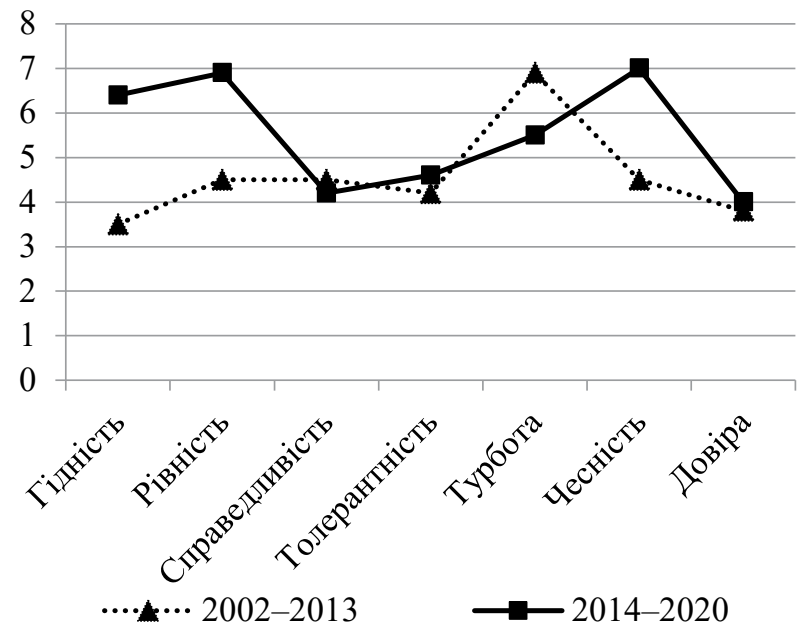

a)

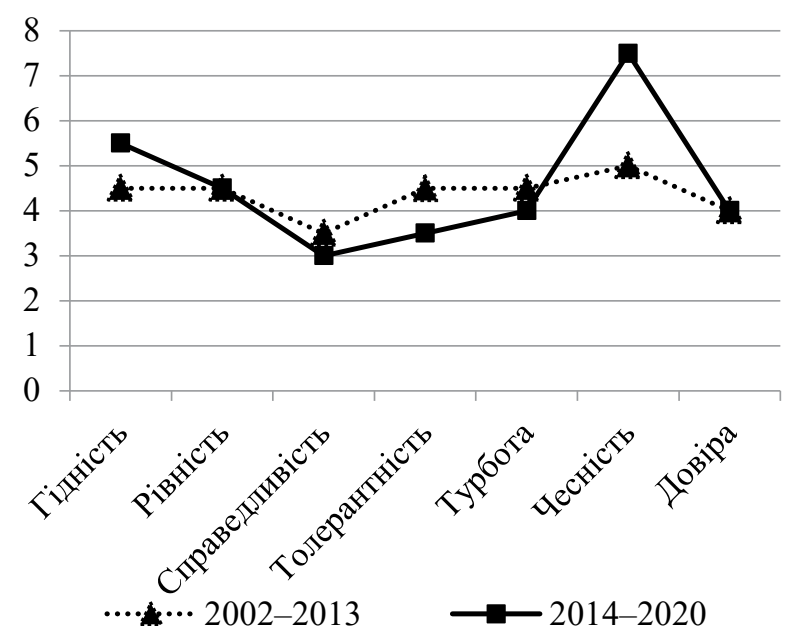

б)

Рис. 1. Зміна конфігурації профрілів ціннісних орієнтацій студентів і викладачів України у 2002-2013 рр. та 2014-2020 рр.: а) студенти; б) викладачі

Джерело: результати власних досліджень 
Друге: 18-річне дослідження було поділене на два періоди через виникнення помітних відмінностей у даних обох підгруп після 2013 рр. У підгрупі студентів найбільше зростання спостерігається за показниками «Гідність», «Рівність» та «Чесність». Водночас присутність характеристики «Турбота» суттєво зменшилася. Ми вважаємо, що головними чинниками зазначених змін у ЦО студентів стали такі: вплив подій Революції Гідності 2013-2014 рр. на самосприйняття та переосмислення ЦО молодими людьми, а також зміна поколінь. За 18 років виросло нове покоління, яке значною мірою є продуктом активізації інформаційних технологій, у т.ч. інфрормаційних війн, які безумовно вплинули на рівень цинізму у сприйнятті реальності.

Третє: звертають на себе увагу досить низькі оцінки таких характеристик як «Довіра», «Толерантність», «Чесність» та «Справедливість». Причому, якщо у студентів перші три характеристики у другому періоді покращилися, то у викладачів маємо погіршення, хоч і незначне. Це могло бути під впливом завищених очікувань від реформи в освіті, яка від початку вже пережила кілька змін векторів. Негативний вплив від відсутності постійного вектора та адекватної стратегії розвитку посилилося передчасністю прийняття рішення про розширення автономії університетів, яку їх адміністрація використала переважно для розбудови бюрократії та звуження прав і свобод співробітників. Зрозуміло, що це стало також додатковим чинником погіршення віри у справедливість в обох досліджуваних групах.

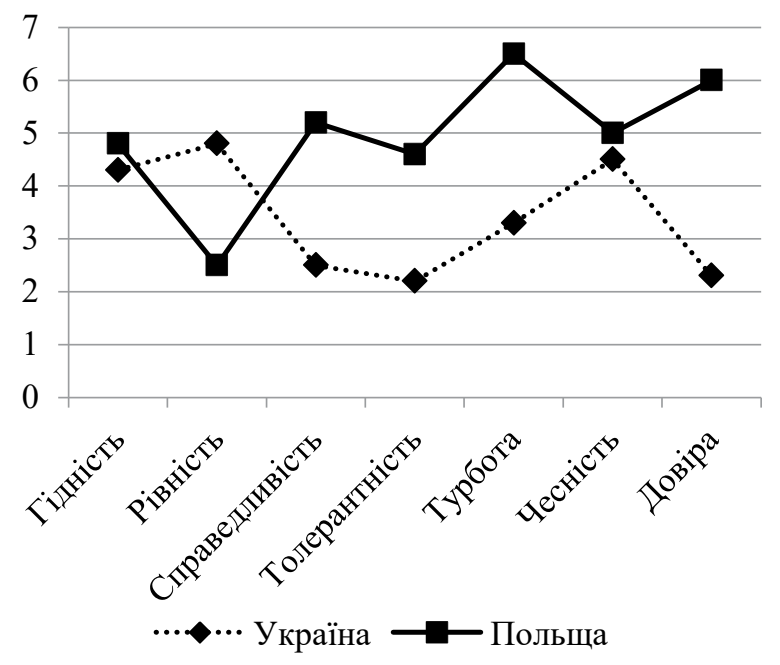

a)
Четверте: динаміка показника «Турбота» була протилежною у досліджуваних групах, що пояснюється відмінністю фрункцій у студентів і викладачів. Викладачі українських університетів, які останнім часом зіштовхнулися з тенденцією до зменшення кількості студентів (у т.ч. через виїзд на навчання за кордон), а також з ризиками, спричиненими COVID-19, все більше виявляють свою турботу у відносинах зі студентами. Водночас студенти через властивий юнацький максималізм, а також причини, описані вище, навпаки, характеризуються вищим рівнем егоїзму та егоцентризму і сконцентровані більше на власній персоні, ніж на турботі про інших.

У пошуках відповіді на питання щодо можливого позитивного впливу гармонізації стандартів освітни України зі стандартами ЄС на більш глибоке сприйняття ЦО студентами і викладачами провели порівняння результатів оцінювання аналогічних характеристик польських і українських представників університетів (рис. 2).

Якщо у ході оцінювання цО студентів i викладачів України відправною точкою були десрініції у нормативних документах, то для аналогічної оцінки представників освіти Польщі базою для порівняння стали співставні характеристики українських представників.

Як свідчать дані рис. 2, незважаючи на близькість України та Польщі 3 багатьох аспектів (географрічної локалізації та природніх умов; історичного, політичного, соціально-економічного та культурного розвитку; подібності менталітету та мови), конфрігура-

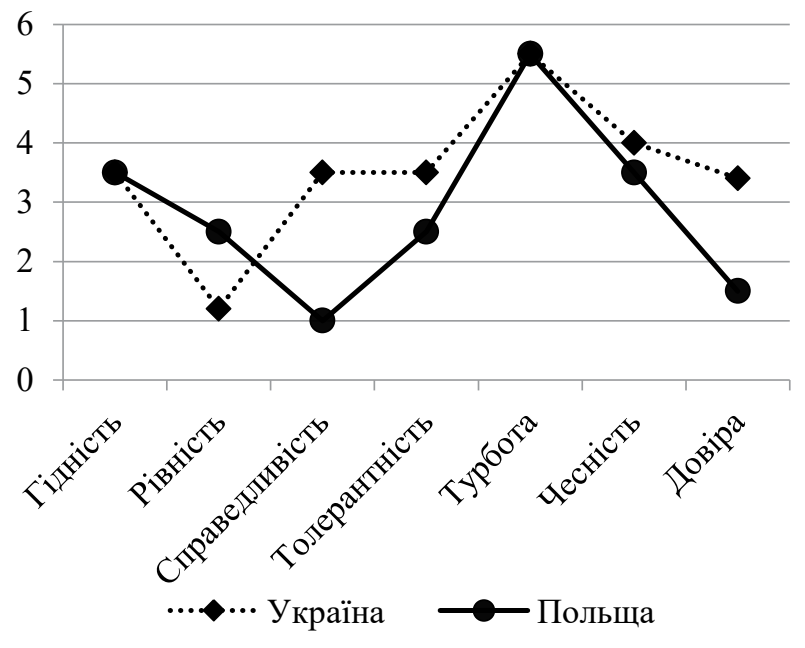

б)

Рис. 2. Порівняння конфігурації профрілів ціннісних орієнтацій особистості України та Польщі у 2014-2020 рр.: а) студентів; б) викладачів 
ції профрілів ЦО досліджуваних груп багато в чому не збігалися. За винятком характеристики «Рівність», усі інші отримали вищі оцінки. Цей фракт, який можна кваліфрікувати як «більш виражені характеристики у поведінці особистості», ми пояснюємо кількома причинами.

По-перше, Польща була під значно більшим впливом раціональної європейської цивілізації (в силу різних причин) набагато довший період часу, ніж Україна. По-друге, навіть у 1939-1980-х рр., коли і Польща, і Україна перебували під впливом цінностей, пропагованих імперією СРСР, у Польщі не відбулося такого руйнування традицій, релігійних і інших культурних інституцій, що століттями фрормували ЦО населення, як це сталося в Україні. По-третє, від моменту входження Польщі до складу $€ C$ у 2004 р. країна отримала багатомільярдні інвестиції, а отже і суттєвий поштовх до соціально-економічного і інших видів розвитку, що не могло не сорормувати відносно високий рівень таких характеристик як «Справедливість», «Толерантність», «Турбота», «Чесність» і «Довіра» - особливо це стосується молодшого покоління.

Отримані у ході спостереження дані, викладені у цій статті, були підтверджені даними, зібраними методом глибинного інтерв'ювання учасників освітнього процесу. Однак, з огляду на ліміт дозволеного обсягу публікації, ці дані, разом із пропозиціями застосування системного підходу для усунення виявлених тенденцій, будуть представлені у наступній статті.
Висновки. Зростаючий розрив між темпами технологічного та гуманітарного розвитку суспільства збільшує ймовірність настання різного роду ризиків, спричинених недостанім рівнем підготовленості виконавців до використання сучасних технологій. Адже новітні технології часто характеризуються значною швидкістю операцій і масштабуванням ефректів, що, крім спеціальних знань 3 предметної області, потребує високого рівня відповідальності і інших характеристик, які складають поняття «ціннісні орієнтири особистості». Це спонукає науковців до пошуків шляхів зменшення, а в перспективі і нівелювання зазначеного вище розриву. Одну із можливостей вирішення проблеми автори вбачають у посиленні гуманітарної складової у виховному процесі. Викладені у цій статті результати спостереження свідчать про недостатню присутність у комплексі характеристик сучасної особистості тих важливих ціннісних орієнтацій, які б свідчили про готовність людей, що складають соціум, усвідомлювати можливі ризики новітніх технологій і гарантувати їх безпечне використання на усіх рівнях життєдіяльності. Ці результати були також підтверджені і поглиблені на основі методу глибинного інтерв'ю учасників освітнього процесу обох країн. Автори переконані у необхідності застосування системного підходу до покращення описаної ситуації. Детальний виклад пропозицій авторів буде опубліковано у наступній статті.

\section{СПИСОК ВИКОРИСТАНИХ ДЖЕРЕЛ:}

1. Андрущенко В. Європейський педагогічний досвід та національні традиції: гармонізація пріоритетів. Вища освіта України. 2014. № 3. 5-11.

2. Бажановська О.В. Роль загальнолюдських цінностей в процесі фрормування громадянина європейської держави. Вісник лдПУ імені Тараса Шевченка. 2003. № 7(63). С. 9-14.

3. Бакіров В.С. Вища школа України: на шляху до європейських стандарті. Академическая мобильность важный фрактор образовательной евроинтеграции Украины : матер. междунар. науч.-практ. конфр., Харків, 16-19 лист. 2010 р. ; редкол. : В.І. Астахова та ін. Харків : Вид-во НУА, 2010. С. 37-46.

4. Безбородих С.М. Аксіологічний підхід в системі професійної підготовки майбутніх фрахівців початкової школи. Вісн. ЛНУ ім. Т. Шевченка. 2011. № 4(215). С. 124-130.

5. Бойко А.І. Проблеми розвитку системи освіти в умовах ринкових трансфрормацій. Вища освіта України. 2008. № 2. C. 34-38.

6. Клепко С.Ф. Філософрія освіти в Європейському контексті : монографрія. Полтава : ПОІППО, 2006. 328 с.

7. Tyckonovych, V. (2019) Humannist' osobystosti: sutnist' ta struktura [Humanity of personality: essence and structure]. Pedagogika ta psyckologiia, vol. 55, pp. 90-98.

8. Ckytra, V. (2013) Teoretychni aspekty vyznachennia zmistu poniattia „vidpovidal'nist' osobystosti. Naukovi zapysky. Seriia: pedagogichni nauky, vol. 122, pp. 382-389.

9. Shaygorods'kyy, Yu. (2010) Tsinnisni oriientatsiyi osobystosti: formalizovana model' tsilisnogo, bagatoaspektnogo analizu. Sothial'na psyckologiya, no. 1(39), pp. 94-106. Retrieved from: https://core.ac.uk/reader/77240790

10. Polozhennia pro organizatsiyu osyitniogo procesu v KPI im. Ihora Sikorskogo (2020) [Regulations on the organization of the educational process in KPI Igor Sikorsky]. Retrieved from: https://kpi.ua/regulations 
11. Kodeks chesti Natsional'nogo tecknichnogo uniwersytetu Ukrayiny „Kyyivs'kyy politecknichnyy instytut” (2015) [Code of Honor of the National Technical University of Ukraine "Kyiv Polytechnic Institute"]. Retrieved from: https://kpi.ua/code

12. Entsyklopediia suchasnoyi Ukrayiny (2020) [Encyclopedia of Modern Ukraine]. Retrieved from: http://esu.com.ua/search_articles.php?id=24649

13. Ustawa z dnia 14 grudnia 2016 r. Prawo oświatowe (Dz. U. z 2020 r. poz.910) ogłoszono dnia 22 maja 2020 r. obowiązuje od dnia 1 września 2017 r. Retrieved from: https://www.prawo.vulcan.edu.pl/przegdok.asp? qdatprz=akt\&qplikid=4186

\section{REFERENCES:}

1. Andrushchenko V. (2014) Europeyskyy pedagogichnyy dosvid ta natsionalni tradytsii: harmonizatsiia priorytetiv [European pedagogical experience and national traditions: harmonization of priorities]. Vyshcha osvita Ukrainy, no. 3, pp. 5-11. Retrieved from: http://enpuir.npu.edu.ua/bitstream/123456789/17568/1/Andrushchenko.pdf

2. Bazhanovska O.V. (2003) Role of values in the process of European state citizen formation. Bulletin T. Shevchenko LDPU, no. 7(63), pp. 9-14.

3. Bakirov V.S. (2010) High School in Ukraine: tracking the way to European standards. Academic mobility is an important factor for educational eurointegration of Ukraine: intern. scient. and pract. conf., Kharkiv, November 16-19, 2010 r. ; edit. staff: V.I. Astakhov and coll. Kharkiv : NUA Print, pp. 37-46.

4. Bezborodykh S.M. (2011) Axiological approach in the professional training system of future primary school specialists. Bulletin T. Shevchenko LNU, no. 4(215), pp. 124-130.

5. Boiko A.I. (2008) Problems in development of education system under the conditions of market transformations. Vyshcha osvita Ukrainy, no. 2, pp. 34-38.

6. Klepko S. (2006) Philisophiia osovity v yevropeys'komu konteksti: monographiya [Philosophy of education in European context: monograph]. Poltava: POIPPO, $328 \mathrm{p}$.

7. Tyckonovych V. (2019) Humannist' osobystosti: sutnist' ta struktura [Humanity of personality: essence and structure]. Pedagogika ta psyckologiia, vol. 55, pp. 90-98.

8. Ckytra V. (2013) Teoretychni aspekty vyznachennia zmistu poniattia „vidpovidal'nist' osobystosti. Naukovi zapysky. Seriia: pedagogichni nauky, vol. 122, pp. 382-389.

9. Shaygorods'kyy Yu. (2010) Tsinnisni oriientatsiyi osobystosti: formalizovana model' tsilisnogo, bagatoaspektnogo analizu. Sothial'na psyckologiya, no. 1(39), pp. 94-106. Retrieved from: https://core.ac.uk/reader/77240790

10. Polozhennia pro organizatsiyu osyitniogo procesu v KPI im. Ihora Sikorskogo (2020) [Regulations on the organization of the educational process in KPI Igor Sikorsky]. Retrieved from: https://kpi.ua/regulations

11. Kodeks chesti Natsional'nogo tecknichnogo uniwersytetu Ukrayiny „Kyyivs'kyy politecknichnyy instytut” (2015) [Code of Honor of the National Technical University of Ukraine "Kyiv Polytechnic Institute"]. Retrieved from: https://kpi.ua/code

12. Entsyklopediia suchasnoyi Ukrayiny (2020) [Encyclopedia of Modern Ukraine]. Retrieved from: http://esu.com.ua/search_articles.php?id=24649

13. Ustawa z dnia 14 grudnia 2016 r. Prawo oświatowe (Dz. U. z 2020 r. poz.910) ogłoszono dnia 22 maja 2020 r. obowiązuje od dnia 1 września 2017 r. Retrieved from: https://www.prawo.vulcan.edu.pl/przegdok.asp?qdatprz=akt\&qplikid $=4186$ 